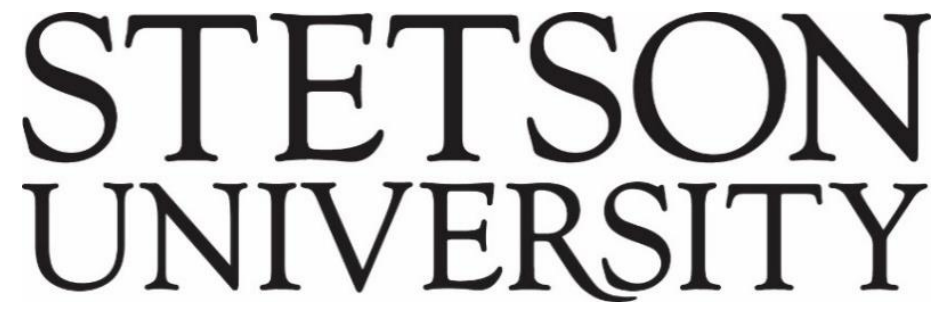

Voices of Reform: Educational Research to Inform and Reform

Volume $3 \bullet$ Issue $1 \bullet$ Article 8

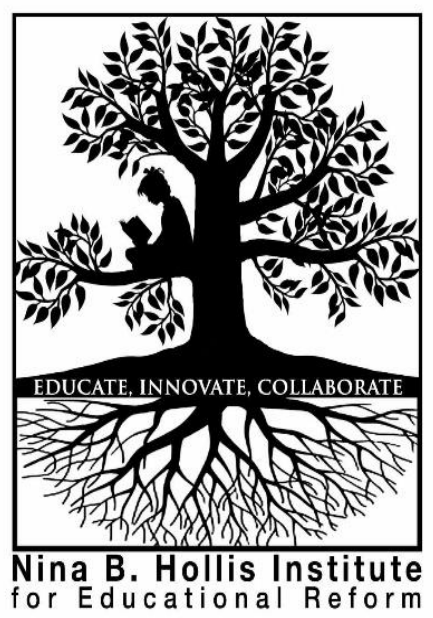

May 2020

\title{
Nina B. Hollis Research Impact Award Project: Garden-Based Learning
}

\author{
Sarah Cramer \\ Stetson University \\ Mercedes Tichenor \\ Stetson University
}

Follow this and additional works at: http://www.voicesofreform.com

\section{Recommended Citation}

Cramer, S. \& Tichenor, M. (2020). Nina B. Hollis Research Impact Award project: Garden-based learning. Voices of Reform, 3(1), 139-145. Retrieved from https://www.voicesofreform.com/article/12777-nina-b-hollis-researchimpact-award-project-garden-based-learning doi: 10.32623/3.00010

http://dx.doi.org/10.32623/3.00010

Revisions

Submission date: November $19^{\text {th }}, 2019$

Acceptance: January $22^{\text {nd }}, 2020$

Publication date: May $1^{\text {st }}, 2020$ 


\title{
Nina B. Hollis Research Impact Award Project: Garden-Based Learning
}

\author{
Sarah Cramer $^{1}$ \\ Mercedes Tichenor ${ }^{2}$ \\ ${ }^{1}$ Department of Environmental Science and Studies \\ Stetson University, United States \\ scramer@stetson.edu \\ ${ }^{2}$ Department of Education \\ Stetson University, United States \\ mticheno@stetson.edu
}

\begin{abstract}
School gardens have been shown to increase physical activity and fruit and vegetable consumption, improve student attitudes towards school, decrease problematic behaviors or behaviors associated with attention deficit disorder, and effectively engage students of diverse backgrounds and learning styles. Despite these benefits, many traditionally prepared classroom teachers are not equipped with the skills necessary to successfully integrate garden-based learning into their pedagogy. The Garden-Based Learning Project was developed as a collaboration between Stetson University and a local elementary school to address the gap between the national enthusiasm for school gardens, and the varying levels of comfort with garden-based learning among teachers. In this article, we describe the first year of the Garden-Based Learning Project, highlighting the project's accomplishments and plans for sustainability in subsequent years.
\end{abstract}

\section{Keywords}

garden-based learning, university-school partnerships, professional development

\section{About Our Project}

Garden-based learning is a popular educational movement that offers many benefits for students. School gardens have been shown to improve student attitudes towards school, increase fruit and vegetable consumption, boost physical activity, decrease problematic behaviors or behaviors associated with attention deficit disorder, and effectively engage students of diverse backgrounds and learning styles (Berezowitz, Bontrager Yoder, \& Schoeller, 2015; Blair, 2009). Despite these benefits, Blair (2009) acknowledges that teacher comfort levels with garden-based learning vary widely, and that there is often a fundamental tension between the philosophy of garden-based 
learning and the traditional approach to elementary education, which prevents school garden programs from reaching their fullest potential (Cramer \& Ball, 2019). The Garden-Based Learning Project, funded by the Hollis Institute for Educational Reform, was developed as a collaboration between the University and a local elementary school to address the gap between the national enthusiasm for school gardens, and the varying levels of comfort with garden-based learning among teachers. Specifically, the goals of the garden-based learning project were: 1) to develop professional development workshops for teachers on incorporating garden-based learning in their classrooms, 2) to increase teacher utilization of school garden plots, 3) to increase the amount of time students spent in garden-based learning, 4) to incorporate garden-based learning into school literacy initiatives to improve student achievement, 5) to advance research on effective methods of including garden-based learning in teacher preparation programs, and 6) to expose university students, both education and non-education majors, to school gardening. In this article, we describe the first year of the Garden-Based Learning Project, highlighting the project's accomplishments and plans for sustainability in subsequent years.

The elementary school selected for this project was a Title 1 school with over $90 \%$ of students receiving free and reduced lunch, and had a high percentage of English language learners, with Hispanic being the majority student demographic of the school. The school was chosen because of its established garden infrastructure and administrative support. The principal was an enthusiastic proponent of the school garden, and a passionate advocate for the project and for additional transformation of both school culture and school nutrition. Though enthusiasm for the gardens was high at the elementary school, there was also a need for more professional development and resources to equip teachers with the skills necessary to independently incorporate their garden plots into their teaching.

The professional development aspect of the project provided teachers with basic gardening skills, access to an established garden-based learning curriculum tied to educational standards, and ideas for utilizing the garden to enhance all academic subjects. In addition to the professional development workshops, funding from the grant provided a garden-themed collection of fiction and non-fiction books for the school media center (drawing largely from the Junior Master Gardener "Growing Good Kids" award winners), a copy of Life Lab's The Growing Classroom curriculum for every teacher, and provided university student volunteers to support teachers in taking their classes outside to garden.

This project expanded garden-based learning in the school environment by engaging three distinct populations: elementary students, classroom teachers, and university students. University student participants in the project came, primarily, from the Department of Education, the Department of Environmental Science and Studies, and/or the Sustainable Food Systems program. Individual students' roles and responsibilities at the school varied, depending upon their reason for participating. The project was led by two university faculty members, the article authors, who together represented both the Education Department and the Environmental Science and Studies Department. At the end of the first year, every garden bed at the elementary school campus was planted, and several teachers were independently visiting the gardens with their class on a weekly 
basis. In the list below, we highlight the accomplishments from year one for each established goal of the Garden-Based Learning Project.

\section{Accomplishments of the Garden-Based Learning Project}

1. Design and implement a professional development workshop series for teachers on incorporating garden-based learning in their classrooms.

- Thirteen teachers attended the professional development session where an overview of basic gardening techniques and how to use The Growing Classroom text was provided - all teachers with a classroom garden bed received a copy of The Growing Classroom curriculum.

- All teachers and university student volunteers received a copy of the school gardening tip sheet developed by project leaders (forthcoming in New Teacher Advocate).

\section{Increase teacher utilization of existing school garden plots.}

- Participants built a garden shed at the school, cleared and repaired garden beds to support teacher use upon return from winter break.

- Teachers received support from university students to increase the utilization of their garden plots. A university student created a map with labels to organize which garden bed belonged to which teacher. Pre-K, $1^{\text {st }}$, and $4^{\text {th }}$ grade teachers were involved most heavily in gardening with their students - planting and watering them daily. By the end of the semester, formerly empty garden beds were producing greens, watermelons, carrots, squash, herbs, and much more! Every bed was in use by the end of the school year, and a new bed was built for the cafeteria to use.

- Teachers from this school and the school selected for year two of the project attended the National Children and Youth Garden Symposium to represent the project and bring back ideas to share with their colleagues. This was a great way to equip a few key teachers to expand and continue garden programming. The symposium brings together people from all over the country for networking and professional development in youth gardening.

- Project leaders led focus groups with all grade level teams to reflect on the year and plan for the next phase of the project. Each focus group was concluded with a final question, "What advice would you have for teachers who would like to garden with their students?" and nearly always got a resounding response to "Just do it!" Despite the challenges, frustrations, and sometimes outright gardening failures the teachers discussed, they all agreed that some gardening, even unsuccessful gardening, was better than nothing. 


\section{Increase teacher utilization of existing school garden plots.}

- A full-day "garden kick-off" was held at the beginning of the project, during which all teachers and classes rotated through the art room to learn about the garden project. In small groups, students participated in guided activities at various garden sites on campus.

- Pre-K, $1^{\text {st }}$, and $4^{\text {th }}$ grade students were involved in a minimum of 20 minutes of gardening each week - usually led by a university student in conjunction with their classroom teacher. Other teachers incorporated gardening more sporadically but still gardened with their students more than they had previously.

\section{Incorporate garden-based learning into school literacy initiatives to improve student achievement.}

- The Garden-Based Learning Project team participated in a literacy night/fall festival event at the school. In addition to promoting the project by handing out labeled seed packets, and sharing garden books and curriculum, there was a garden-themed literacy activity at the team's booth. Using laminated grade-level appropriate words, students built garden-themed sentences and in return received fresh fruit (a healthy take on the "trunk or treat" element of the festival).

- Forty-four garden/agriculture-themed books were purchased for donation to the school media center (most selected from the "Growing Good Kids" Award list). The media specialist tracked their use and has incorporated them into media lessons.

\section{Advance research on effective methods of including garden-based learning in teacher preparation programs.}

- Project leaders completed a qualitative assessment of pre-service teachers' perceptions of garden-based learning. Interviews were conducted with eight elementary education interns, data was analyzed, and a manuscript was submitted for publication.

\section{Expose university students from both education and environmental studies/food system programs to school gardening and garden-based learning.}

- An education major working on an independent study project handled most of the coordination and much of the hands-on gardening. Two sustainable food systems students and three education students completed their community engagement hours helping teachers lead their students in gardening. During the focus groups, teachers unanimously agreed that they would not have gardened with the students without the help of university volunteers, and that their experiences with the volunteers were overwhelmingly positive. 


\section{Reflections on year one and next steps}

During the first year of this grant, we focused our efforts on key teachers who demonstrated the most interest and enthusiasm in the garden project. Though these efforts were not spread universally across the student population, the classrooms with which we worked most closely experienced a significant increase in time engaged in garden-based learning. Pre-K, 1st, and 4th grade students were involved in a minimum of 20 minutes of gardening each week - usually led by a university student in conjunction with their classroom teacher.

As we look to next year and the future of the project, we plan to expand to other Title 1 schools, while continuing to monitor the pilot project to establish the efficacy of the program in improving academic achievement. We will remain involved at the original school through the continued presence of university student interns and volunteers and, as needed, professional development.

The elementary school was chosen as the initial site with the long-term sustainability of the project in mind. Because of its established garden infrastructure, supportive principal, and enthusiastic faculty and staff members, the school had already avoided many of the traps into which school garden programs fall and faced less risk of failure than another school might (Ozer, 2007). To set the project up for continued success and longevity, we have cultivated a network of community partners that can support the programming after the Nina B. Hollis Research Impact Grant funding ends, such as University of Florida Extension Master Gardeners, the University of Florida Extension SNAP Education, and Lowe's home improvement store. In fact, a partnership between the elementary school and Lowe's has already been facilitated to source vegetable seeds and garden supplies. Further, we are developing partnerships with Green Volusia, a program of the local county government, whose staff are involved in related environmental education projects, and who have offered to serve as a conduit for distributing funding to projects like ours. Other sources for future grant support of the project include Lowe's Charitable and Education Foundation and Publix's Community Giving program. Additional sources of funding could be school garden specific grants, such as Youth Garden Grant, Budding Botanist, Carton to Garden, Gro More Good Grassroots Grant, and Annie's Grant for Gardens. The initial investment in curriculum, books, professional development, and garden infrastructure at the elementary school will allow the garden-based learning project to be largely self-sustaining in the coming years. Minor ongoing maintenance costs (replacement tools, repairs to garden beds, seeds, soil amendments) can be covered by grants or donations of time/money/supplies from community partners described above. We are excited to see how this school gardening project will continue to impact teachers and students. 


\section{References}

Berezowitz, C.K., Bontrager Yoder, A.B., \& Schoeller, D.A. (2015). School gardens enhance academic performance and dietary outcomes in children. Journal of School Health, 85(8), 508-518.

Blair, D. (2009). The child in the garden. An evaluative review of the benefits of school gardening. The Journal of Environmental Education, 40(2), 15-38.

Cramer, S.E. \& Ball, A.L. (2019). Wild leaves on narrow STEMs: Exploring formal and non-formal educational tensions through garden-based learning. Journal of Agricultural Education, 60(4). Retrieved from https://doi.org/10.5032/jae.2019.04035

Growing Good Kids Book Awards. (n.d.). Retrieved from http://jmgkids.us/bookawards/

Jaffe, R., \& Appel, G. (2014). The growing classroom: Garden-based science and nutrition activity guide. Williston, VT: National Gardening Association.

Ozer, E.J. (2007). The effects of school gardens on students and schools: Conceptualization and considerations for maximizing healthy development. Health Education \& Behavior, 34(6), 846-863. 